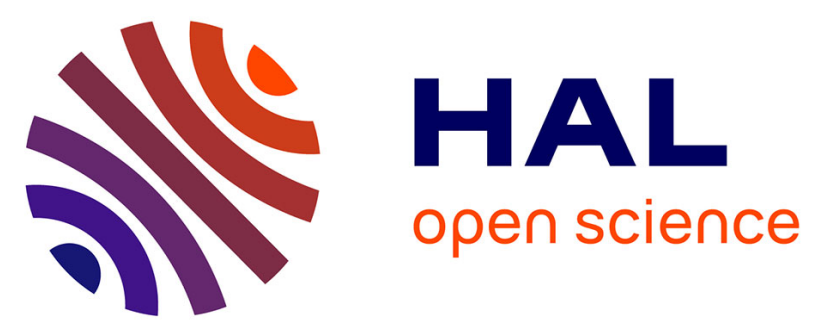

\title{
Evaluation of haemodialysis as a protective technique for preventing high daily dose amikacin nephrotoxicity: an experimental study in an ovine model.
}

Céline Pouzot Pouzot-Névoret, Mathieu Magnin, Jean-Yves Ayoub, Laurent Bourguignon, Pascal Maire, Damien Wertz, Isabelle Goy-Thollot, Anthony

Barthélemy, Emmanuel Boselli, Bernard Allaouchiche, et al.

\section{To cite this version:}

Céline Pouzot Pouzot-Névoret, Mathieu Magnin, Jean-Yves Ayoub, Laurent Bourguignon, Pascal Maire, et al.. Evaluation of haemodialysis as a protective technique for preventing high daily dose amikacin nephrotoxicity: an experimental study in an ovine model.. International Journal of Antimicrobial Agents, 2017, 10.1016/j.ijantimicag.2017.03.029 . hal-02458478

\section{HAL Id: hal-02458478}

https://hal-vetagro-sup.archives-ouvertes.fr/hal-02458478

Submitted on 28 Jan 2020

HAL is a multi-disciplinary open access archive for the deposit and dissemination of scientific research documents, whether they are published or not. The documents may come from teaching and research institutions in France or abroad, or from public or private research centers.
L'archive ouverte pluridisciplinaire HAL, est destinée au dépôt et à la diffusion de documents scientifiques de niveau recherche, publiés ou non, émanant des établissements d'enseignement et de recherche français ou étrangers, des laboratoires publics ou privés. 


\section{Evaluation of hemodialysis as a protective technique for preventing high daily dose amikacin nephrotoxicity: an experimental study in an ovine model}

Céline Pouzot-Nevoret $^{\mathrm{a}, \mathrm{b}}$, Mathieu Magnin ${ }^{\mathrm{a}, \mathrm{b}}$, Jean-Yves Ayoub $^{\mathrm{b}}$, Laurent Bourguignon ${ }^{\mathrm{c}}$, Pascal Maire ${ }^{\mathrm{c}}$, Damien Wertz ${ }^{\mathrm{d}}$, Isabelle Goy-Thollot ${ }^{\mathrm{a}, \mathrm{b}}$, Anthony Barthélemy ${ }^{\mathrm{a}, \mathrm{b}}$, Emmanuel Boselli $^{\mathrm{b}}$, Bernard Allaouchiche $\mathrm{b}^{\mathrm{b}, \mathrm{e}}$, Jeanne Marie Bonnet-Garin ${ }^{\mathrm{b}}$

${ }^{\text {a }}$ Intensive Care Unit (SIAMU), Université de Lyon, VetAgro Sup, APCSe Agressions Pulmonaires et Circulatoires dans le Sepsis, Université de Lyon, 69280, Marcy-l'Étoile, France.celine.pouzotnevoret@ vetagro-sup.fr, mathieu.magnin@vetagro-sup.fr, anthony.barthelemy@vetagro-sup.fr, isabelle.goy-thollot@vetagro-sup.fr.

${ }^{\mathrm{b}}$ Université de Lyon, VetAgro Sup, APCSe Agressions Pulmonaires et Circulatoires dans le Sepsis, 69280, Marcy-l’Étoile, France. jean-yves.ayoub@vetagro-sup.fr, jeannemarie.bonnet@vetagro-sup.fr. emmanuel.boselli@gmail.com ${ }^{\mathrm{c}}$ Hospices Civils de Lyon, Hôpital Antoine Charial, Service Pharmacie, 69340, Francheville, France.1aurent.bourguignon@chu-lyon.fr, pascal.maire@chu-lyon.fr.

${ }^{\mathrm{d}}$ Department of General Intensive Care, University Hospital of Liege, Liège, Belgium. damien.wertz@alumni.ulg.ac.be

${ }^{\mathrm{e}}$ Hospices Civils de Lyon, Centre Hospitalier Lyon-Sud, Service de Réanimation, 69310, Pierre Bénite, France. bernard.allaouchiche@chu-lyon.fr.

Corresponding author: Céline Pouzot-Nevoret, celine.pouzotnevoret@vetagro-sup.fr, 1 avenue Bourgelat, 69280 Marcy L'Etoile, France, +33 (0)4 788707 07, +33 (0)4 788727 $\underline{96}$ 
Changes in pharmacokinetic parameters of critical ill patients make the treatment of infections challenging, particularly when multidrug-resistant bacteria are involved. The aim of this study was to evaluate the ability of hemodialysis to reduce the exposure to high dose amikacin and prevent nephrotoxicity. Amikacin $50 \mathrm{mg} / \mathrm{kg}$ was administered intravenously to 6 adult sheep once daily for 4 days. Sheep were divided into two groups according to the implementation (group 1) or not (group 2) of hemodialysis. In group 1, hemodialysis was performed for $4 \mathrm{~h}$, initiated $2 \mathrm{~h}$ after starting amikacin infusion. Amikacin area under the curve (AUC) and trough concentrations $\left(\mathrm{C}_{\mathrm{min}}\right)$ were used as markers of amikacin-induced nephrotoxicity. The median hemodialysis amikacin clearance was $2.14 \mathrm{~L} / \mathrm{h}(35.6 \mathrm{~mL} / \mathrm{min})$, $14 \%$ of the mean total body clearance for $24 \mathrm{~h}$. Hemodialysis reduced $\mathrm{C}_{\min }$ (group 1: 0.3 $\mu \mathrm{g} / \mathrm{mL}[0.3-1.1]$; group 2: $1.4 \mu \mathrm{g} / \mathrm{mL}$ [1.1 - 3.9]; $\mathrm{P}=0.0003)$ and time of exposure to a concentration exceeding $2.5 \mu \mathrm{g} / \mathrm{mL}$ (group 1: $99.7 \%$ [99.7 - 99.8]; group 2: $99.9 \%$ [99.8 99.9]; $\mathrm{P}=0.049$ ). A trend toward reduced AUC with hemodialysis was observed (group 1: $1450 \mu \mathrm{g} / \mathrm{mL} . \mathrm{h}$ [1311 - 1716]; group 2: $3126 \mu \mathrm{g} / \mathrm{mL} . \mathrm{h}$ [2581 - 3171]; $\mathrm{P}=0.10$ ). No sheep has developed acute kidney injury. In conclusion, hemodialysis seems interesting in reducing AUC and $\mathrm{C}_{\min }$ after injection of high-dose of amikacin, parameters known to be involved in its induced nephrotoxicity, in an experimental ovine model.

Keywords

Amikacin-induced nephrotoxicity, pharmacokinetics, hemodialysis, multidrug-resistant bacteria

Abbreviations

AKI: acute kidney injury

AUC: area under the curve

$\mathrm{Cl}_{\mathrm{cr}}$ : creatinine clearance

$\mathrm{Cl}_{\mathrm{d}}$ : hemodialysis clearance of amikacin

$\mathrm{Cl}_{\mathrm{r}}$ : renal clearance of amikacin

$\mathrm{C}_{\text {max }}$ : maximal concentration

$\mathrm{C}_{\text {min }}$ : trough concentration

$\mathrm{CV}$ : coefficient of variation

ICU: intensive care unit 
MDR: multidrug-resistant bacteria

MIC: minimal inhibitory concentration

RRT: renal replacement therapy

$\mathrm{V}_{\mathrm{d}}$ : volume of distribution

VPC: Visual Predictive Check

\section{Introduction}

Multidrug-resistant (MDR) bacteria are tremendously emerging in the intensive care unit (ICU) environment, increasing mortality and morbidity of critically ill patients [1]. The treatment of these patients is challenging as only few new drugs have been developed in recent years. New strategies need to be promoted in order to optimize the use of available antibiotics [2].

Aminoglycosides are important drugs for the treatment of sepsis and septic shock with involvement of Gram-negative pathogens [3-8]. Among the aminoglycosides, amikacin is a well-used concentration-dependent antibiotic. Optimum antibacterial effect is obtained when the ratio between the maximal concentration $\left(\mathrm{C}_{\max }\right)$ of the drug and its minimal inhibitory concentration (MIC) is more then 8 [2]. This target is also related to a better clinical response [9]. For amikacin, the MIC of Enterobacteriaceae and Pseudomonas spp are $8 \mu \mathrm{g} / \mathrm{mL}$ for sensitive strains and $16 \mu \mathrm{g} / \mathrm{mL}$ for intermediate strains [10], indicating that to improve the antibacterial activity, $C_{\max }$ should reach plasma concentrations $\geq 64 \mu \mathrm{g} / \mathrm{mL}$ or $\geq 128 \mu \mathrm{g} / \mathrm{mL}$.

Critically ill patients have modifications of their pharmacokinetic parameters, with increased volume of distribution $\left(\mathrm{V}_{\mathrm{d}}\right)$ due to the large volume of administered fluids and increased vascular permeability resulting in interstitial fluid shifts [2]. Consequently, serum target concentrations of hydrophilic drugs such as amikacin are difficult to obtain. With a dose of amikacin of $\leq 30 \mathrm{mg} / \mathrm{kg}$, a $\mathrm{C}_{\max }$ of $\geq 64 \mu \mathrm{g} / \mathrm{mL}$ is reached in less than $77 \%$ of patients $[4,5,8,11]$. Higher doses than $30 \mathrm{mg} / \mathrm{kg}$ may therefore be needed to achieve the clinical breakpoint in critically ill patients.

Amikacin is a nephrotoxic agent with toxicity related to excessive antibiotic exposure, providing increased area under the time-concentration curve (AUC) and increased trough concentration $\left(\mathrm{C}_{\min }\right)$ [12]. Increasing the amikacin dose will increase these pharmacokinetic parameters, implying increased renal toxicity. With a dose of $25 \mathrm{mg} / \mathrm{kg}$, a $\mathrm{C}_{\min }$ of $>5 \mu \mathrm{g} / \mathrm{mL}$ is observed in more than $50 \%$ of the patients [7]. Acute kidney injury (AKI) is reported in 
$24 \%$ of ICU patients with $30 \mathrm{mg} / \mathrm{kg}$ of amikacin [5]. In this study, survivors had a $\mathrm{C}_{\min }$ significantly lower than non survivors [5].

The use of renal replacement therapy to improve the elimination of the antibiotic and reduce its toxicity after the administration of high dose of amikacin has been reported with success in two cases [6] and was associated with a favorable clinical response in 8 of 15 patients with MDR-induced sepsis [3].

Despite medical and economical concerns, only few data is available on this subject. The aim of the present study was to compare the elimination of a high dose of amikacin (50 $\mathrm{mg} / \mathrm{kg}$ ) in an ovine model between a population of dialyzed and non-dialyzed sheep. We hypothesized that intermittent hemodialysis may reduce the risk of amikacin nephrotoxicity.

2. Material and methods

This study was conducted in accordance with the Guide for the Care and Use of Laboratory Animals and approved by the Ethics Committee of VetAgro Sup (Campus Vétérinaire de Lyon) with the agreement 1548-V2.

\subsection{Animals}

Six adult female sheep weighing from 63 to $81 \mathrm{~kg}$ were included in this study. A 14days acclimation period was implemented before the study. Animals were fed with hay ad libitum and with alfalfa pellets and given free access to water. All sheep were screened by physical examination, complete blood cell count, serum biochemistry, coproscopy and serologic test for Brucella and Coxiella.

\subsection{Animal preparation}

Animals were anesthetized with intramuscular injection of xylazine $(0.1 \mathrm{mg} / \mathrm{kg})$ and midazolam $(0.2 \mathrm{mg} / \mathrm{kg})$, and a $11.5 \mathrm{Fr}$ double lumen catheter (Hemo-cath ${ }^{\circledR}$, Medical Components, Harleysville, PA) was placed with the transcutaneous Seldinger technique [13] in the right jugular vein. A $14 \mathrm{CH}$ Foley urinary catheter (Uromedia ${ }^{\circledR}$, Euromedis, NeuillySous-Clermont, France) was also placed and a one-day recovery period was then allowed.

\subsection{Experimental protocol}


The experimental protocol is detailed in Fig. 1. Urine was collected over one hour with the conventional technique [14] before amikacin administration for urinary creatinine clearance calculation every day from day 2 (considered as the reference value) to day 6 [15]. A single $50 \mathrm{mg} / \mathrm{kg}$ dose of amikacin was then administered intravenously over a 30-min period through the jugular vein every day from day 2 to day 5. Sheep were divided into two groups: with hemodialysis (group 1, $n=3$ ), without hemodialysis (group 2, $n=3$ ). In group 1, hemodialysis was initiated $2 \mathrm{~h}$ after the beginning of the infusion of amikacin from day 2 to day 5 and was performed during 4 h with a Prismaflex dialyzer unit (Prismaflex ${ }^{\circledR}$, Hospal, Meyzieu, France) equipped with a ST100 ${ }^{\circledR}$ set constitute with an artificial kidney with a AN69ST $^{\circledR}$ membrane (Hospal, Meyzieu, France). Blood was pumped at a rate of $160 \mathrm{~mL} / \mathrm{min}$. The dialysate fluid flow rate was set at $1200 \mathrm{~mL} / \mathrm{h}$. The dialysate solution used was Hemosol B0 ${ }^{\circledR}$ (Hospal, Meyzieu, France) supplemented with potassium at $4.5 \mathrm{mmol} / \mathrm{L}$. A low ultrafiltration rate was set at $100 \mathrm{~mL} / \mathrm{h}$ offset by the infusion of a predilution replacement solution. Heparin was used for anticoagulation at 1000 units every hour. In group 2, hemodialysis was not performed.

\section{Figure 1: Study protocol}

\begin{tabular}{|c|c|}
\hline Animal & $\frac{\mathbf{1}}{\text { paration }}$ \\
\hline Groupe 1: hemodialysis & Groupe 2: no hemodialysis \\
\hline $\begin{array}{l}\quad \text { Day } \mathbf{2} \text { to Day } 5 \\
\checkmark \text { T-1h: urinary creatinine clearance measurement } \\
\checkmark \text { T0 } \\
\quad \checkmark \text { Blood sample for amikacin concentration } \\
\text { measurement } \\
\checkmark \text { Amikacin administration } \\
\checkmark \text { Creatinine measurement } \\
\checkmark \text { T+2h to T+6h: Hemodialysis } \\
\checkmark \text { Blood samples for amikacin concentration measurement } \\
\checkmark \text { Day 2: T+1h, T+2h, T+6h } \\
\checkmark \text { Day 3: T0 } \\
\checkmark \text { Day 4: T0, T+1h, T+6h } \\
\checkmark \text { Day 5: T0 }\end{array}$ & $\begin{array}{l}\quad \text { Day } \mathbf{2} \text { to Day } \mathbf{5} \\
\checkmark \text { T-1h: urinary creatinine clearance measurement } \\
\checkmark \text { TO } \\
\checkmark \text { Blood sample for amikacin concentration } \\
\quad \text { measurement } \\
\checkmark \text { Amikacin administration } \\
\checkmark \text { Creatinine measurement } \\
\checkmark \text { Blood samples for amikacin concentration measurement } \\
\checkmark \text { Day 2: T+1h, T+2h, T+6h } \\
\checkmark \text { Day 3: T0 } \\
\quad \checkmark \text { Day 4: T0, T+1h, T+6h } \\
\checkmark \text { Day 5: T0 }\end{array}$ \\
\hline
\end{tabular}

\section{Day 6}

$\checkmark$ T-1h: urinary creatinine clearance measurement

$\checkmark$ TO: Blood samples for amikacin and creatinine concentration measurement 


\subsection{Sampling and analytic method}

Blood samples were collected from the jugular vein at 1,2 and $6 \mathrm{~h}$ after the beginning of the amikacin infusion during day 2; at 0,1 and $6 \mathrm{~h}$ after the beginning of the infusion during day 4 and at $0 \mathrm{~h}$ after beginning the infusion during day 3, 5 and 6. Blood samples were collected in heparinized tubes and were centrifuged. Urine samples were collected every morning for one hour (day 2 to day 6 ) before amikacin administration and their volume was measured. Five $\mathrm{mL}$ of each urine sample were immediately stored at $-80^{\circ} \mathrm{C}$ and protected from light until creatinine analysis. Creatinine was measured with a colorimetric technique realized by Konelab $30^{\circledR}$ (Thermo Fisher Scientific, Waltham, MA). The minimum detectable concentration was $1 \mathrm{mg} / \mathrm{L}$ in serum and $20 \mathrm{mg} / \mathrm{L}$ in urine. Amikacin was measured by an immunoturbidimetric technique realized by Architect $c 8000^{\circledR}$ (Abbott Laboratories, Abbott Park, IL). The minimum detectable concentration in serum was $0.6 \mu \mathrm{g} / \mathrm{mL}$.

\subsection{Nephrotoxicity and AKI}

Comparisons of AUC and $\mathrm{C}_{\min }$ between the two groups were used to evaluate the impact of hemodialysis on nephrotoxicity. As toxicity is associated with amikacin exposure, the time spent with a concentration greater than $2.5 \mu \mathrm{g} / \mathrm{mL}$ was studied. The French National Agency of Drug Safety recommends not to administer another dose of amikacin if the $C_{\min }$ is not below the threshold of $2.5 \mu \mathrm{g} / \mathrm{mL}$ [16]. The AKI was defined by an increase in serum creatinine concentration of $\geq 50 \%$ and/or a decrease in the glomerular filtration rate (GFR, evaluated by the urinary creatinine clearance) of $\geq 25 \%$ between baseline and last day values.

\subsection{Pharmacokinetic analysis}

The pharmacokinetic analysis was based on a compartmental approach using a twocompartment model, as described for amikacin in patients with renal replacement therapy [17]. This model was described by a system of ordinary differential equations as follows:

$$
\begin{aligned}
& d X(1) / d t=-\left[\left(K_{12}+K_{\mathrm{el}}\right) * X(1)\right]+K_{21} * X(2) \\
& d X(2) / d t=-K_{21} * X(2)+K_{12} * X(1)
\end{aligned}
$$

Where $X(1)$ is the amount of amikacin in the principal compartment and $X(2)$ is the amount of amikacin in the second compartment. $K_{12}$ and $K_{21}$ are the transfer rate constants and $K_{\mathrm{el}}$ is elimination rate constant. 
The $\mathrm{V}_{\mathrm{d}}$ was linearly linked to the body weight. Elimination is described by renal elimination linked to creatinine clearance, elimination by hemodialysis in sheep of group 1 and non-renal elimination. The analysis was performed using the non-parametric modeling software Pmetrics $^{\circledR}$ (LAPKB, Hollywood, CA) [18].

Individual pharmacokinetic parameters were determined by Bayesian estimation for each sheep. Adjusted coefficient of determination, bias (mean weighted prediction error) and imprecision (bias-adjusted mean weighted squared prediction error) of concentration predictions were used to measure predictive performance. The validation of the model was made by Visual Predictive Check (VPC) [19].

The residual error was modeled as a polynomial function (describing the assay error) multiplied by a parameter (gamma) taking into account uncertainties of the clinical environment. Error $=$ gamma $\times\left(3.62+0.000975 \mathrm{Y}+0.0 .003454^{2}\right)$, where $\mathrm{Y}$ is observed concentration

\subsection{Statistical analysis}

Statistical analyses were performed using Prism $6^{\circledR}$ software (GraphPad Software, Inc., La Jolla, CA). Continuous variables were expressed as means \pm standard deviation (SD) or median (interquartile range). The value of $0.3 \mu \mathrm{g} / \mathrm{mL}$ was used for amikacin concentration lower than $0.6 \mu \mathrm{g} / \mathrm{mL}$, as non-measurable by the automate. Differences between groups were assessed using the Mann-Whitney $\mathrm{U}$ test. A value of $P<0.05$ was considered to be statistically significant.

3. Results

\subsection{Pharmacokinetic parameters}

The pharmacokinetic parameters are presented in Table 1.

\section{Table 1. Pharmacokinetic parameters}

$\left(\mathrm{Cl}_{\mathrm{r}}\right.$ : renal clearance of amikacin (without unit, it must be multiplied by the creatinine clearance), $\mathrm{Cl}_{\mathrm{cr}}$ : creatinine clearance $(\mathrm{mL} / \mathrm{kg} / \mathrm{min}), \mathrm{Cl}_{\mathrm{d}}$ : hemodialysis clearance of amikacin $(\mathrm{L} / \mathrm{h}), \mathrm{V}_{\mathrm{d}}$ : volume of distribution $(\mathrm{L} / \mathrm{kg}), \mathrm{CV}$ : coefficient of variation (\%)) 


\begin{tabular}{|l|l|l|l|}
\hline & Median & Standard deviation & $\mathrm{CV}$ \\
\hline $\mathrm{Cl}_{\mathrm{r}}$ & 0.04 & 0.01 & 22.55 \\
\hline $\mathrm{Cl}_{\mathrm{Cr}}$ & 2.05 & 0.58 & 31.88 \\
\hline $\mathrm{Cl}_{\mathrm{d}}$ & 2.14 & 0.48 & 20.18 \\
\hline $\mathrm{V}_{\mathrm{s}}$ & 0.19 & 0.03 & 17.34 \\
\hline
\end{tabular}

3.2. Predictive performance

The model had good predictive performance: bias of $-0.55 \mathrm{mg} / \mathrm{L}$, imprecision of $3.94 \mathrm{mg}^{2} / \mathrm{L}^{2}$ and adjusted coefficient of correlation of 0.94 between predicted and observed amikacin concentrations. These predictive performances were improved after Bayesian estimation of individual pharmacokinetic parameters (bias $=-0.02 \mathrm{mg} / \mathrm{L}$, imprecision $=0.76$ $\mathrm{mg}^{2} / \mathrm{L}^{2}$, adjusted coefficient of correlation $\left.=0.99\right)($ Fig 2$)$.

The model was validated by VPC: only three concentrations were not included in the $95 \%$ confidence interval (Fig 3).

Figure 2: Representation of observed versus population predicted concentrations (A), and observed versus individual predicted concentrations (B)
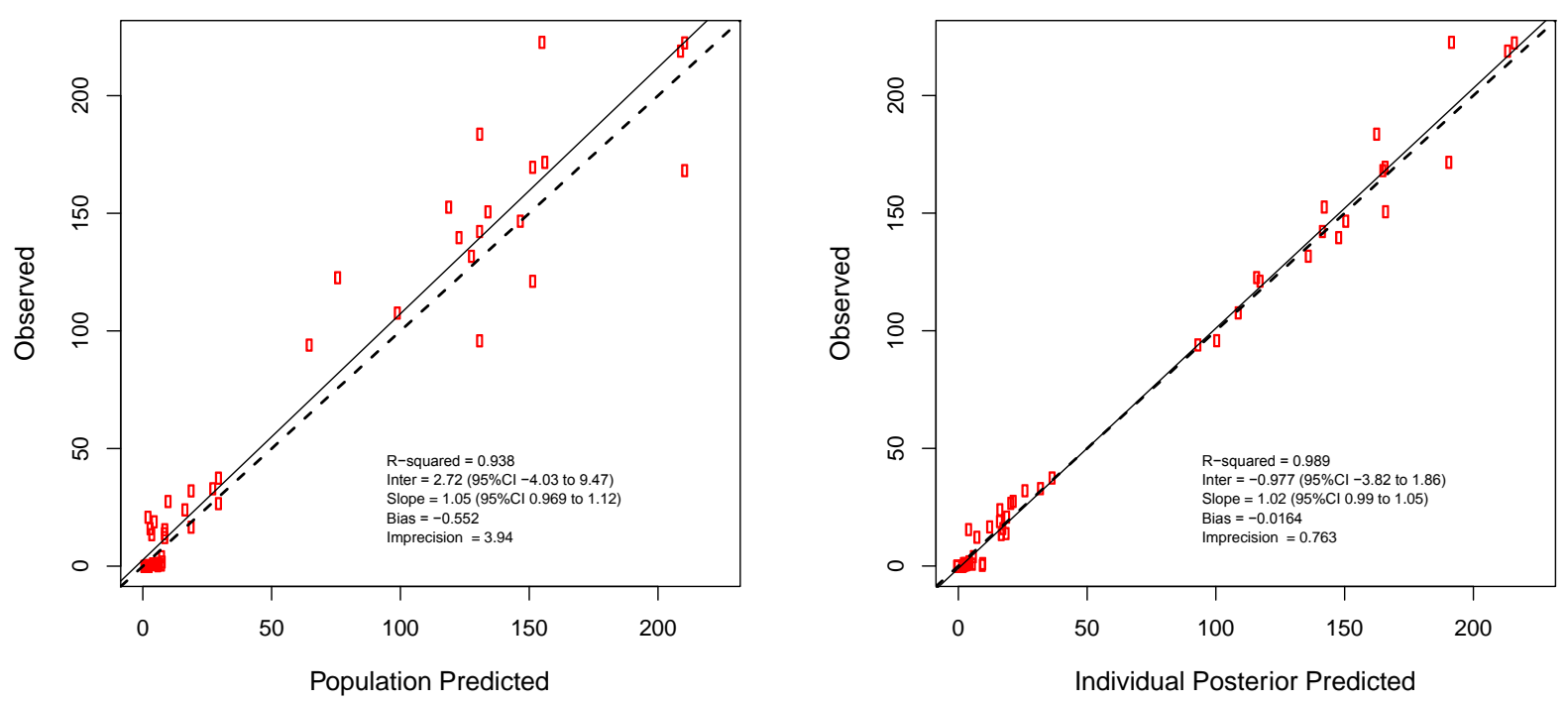
Figure 3: Visual predictive check for the 5th (red) and the 95th percentile (blue)

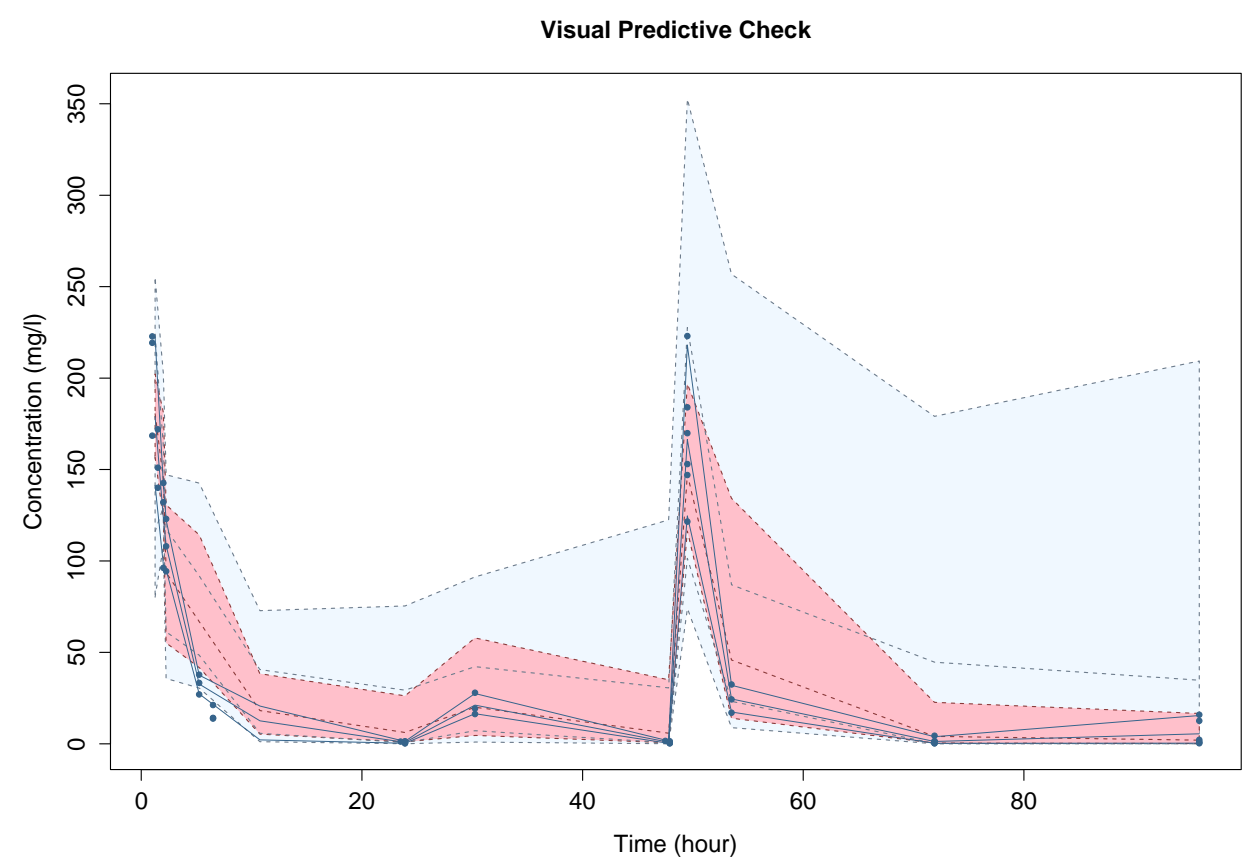

3.3. $\mathrm{C}_{\max }$

The $\mathrm{C}_{\max }$ predicted by the model were used. The medians were $214.1 \mu \mathrm{g} / \mathrm{mL}$ (208.6 - 272.1) in group 1 and $208.3 \mu \mathrm{g} / \mathrm{mL}(165.8-214.2)$ in group $2(P=0.09)$ (Table 2$)$.

Table 2. Maximal concentrations $\left(\mathrm{C}_{\max }\right)$, minimal concentrations $\left(\mathrm{C}_{\underline{\min }}\right)$ and area under the $\underline{\text { time-concentration curve (AUC) of amikacin after the injection of } 50 \mathrm{mg} / \mathrm{kg} \text {. }}$

\begin{tabular}{|c|c|c|c|c|c|c|c|}
\hline & \multicolumn{3}{|c|}{ Group 1 (hemodialysis) } & \multicolumn{2}{c|}{ Group 2 (no hemodialysis) } & \multirow{2}{*}{ P } \\
\hline & Median & $\begin{array}{c}25^{\text {th }} \\
\text { percentile }\end{array}$ & $\begin{array}{c}75^{\text {th }} \\
\text { percentile }\end{array}$ & Median & $\begin{array}{c}25^{\text {th }} \\
\text { percentile }\end{array}$ & $\begin{array}{c}75^{\text {th }} \\
\text { percentile }\end{array}$ & \\
\hline $\begin{array}{c}\mathrm{C}_{\max } \\
(\mu \mathrm{g} / \mathrm{mL})\end{array}$ & 214.1 & 208.6 & 272.1 & 208.3 & 165.8 & 214.2 & 0.09 \\
\hline $\begin{array}{c}\mathrm{C}_{\min } \\
(\mu \mathrm{g} / \mathrm{mL})\end{array}$ & 0.3 & 0.3 & 1.1 & 1.4 & 1.1 & 3.9 & 0.0003 \\
\hline $\begin{array}{c}\mathrm{AUC} \\
(\mu \mathrm{g} / \mathrm{mL} . \mathrm{h})\end{array}$ & 1450 & 1311 & 1716 & 3126 & 2581 & 3171 & 0.10 \\
\hline
\end{tabular}


3.4. Impact of hemodialysis on pharmacokinetic parameters

The median clearance of amikacin by hemodialysis was $2.14 \mathrm{~L} / \mathrm{h}(35.6 \mathrm{~mL} / \mathrm{min})$, $16 \%$ of the total body clearance for $24 \mathrm{~h}$. The $\mathrm{C}_{\min }$ was significantly lower in group 1 compared with group 2 (respectively $0.3 \mu \mathrm{g} / \mathrm{mL}[0.3-1.1]$ and $1.4 \mu \mathrm{g} / \mathrm{mL}[1.1-3.9] ; P=$ 0.0003). The Figure 4 represents the evolution of $\mathrm{C}_{\min }$ during the study in both groups: an increase was observed in sheep from group 2 the last two days. The median AUC tended to be lower in group 1 compared with group 2 (respectively, $1450 \mu \mathrm{g} / \mathrm{mL} . \mathrm{h}$ [1311 - 1716] versus $3126 \mu \mathrm{g} / \mathrm{mL} . \mathrm{h}$ [2581 -3171$] ; P=0.10$ ), although this difference did not reach statistical significance. The time with serum amikacin concentration exceeding $2.5 \mu \mathrm{g} / \mathrm{mL}$ was significantly lower in group 1 compared with group $2(99.7 \%$ [99.7 - 99.8] versus $99.9 \%$ [99.8-99.9]; $P=0.049)$.

Figure 4: Minimal concentrations (abscissa: time, D: day; ordinate: $\mathrm{C}_{\min }(\mu \mathrm{g} / \mathrm{mL})$; triangles: group 1(with hemodialysis), circles: group 2 (without hemodialysis))

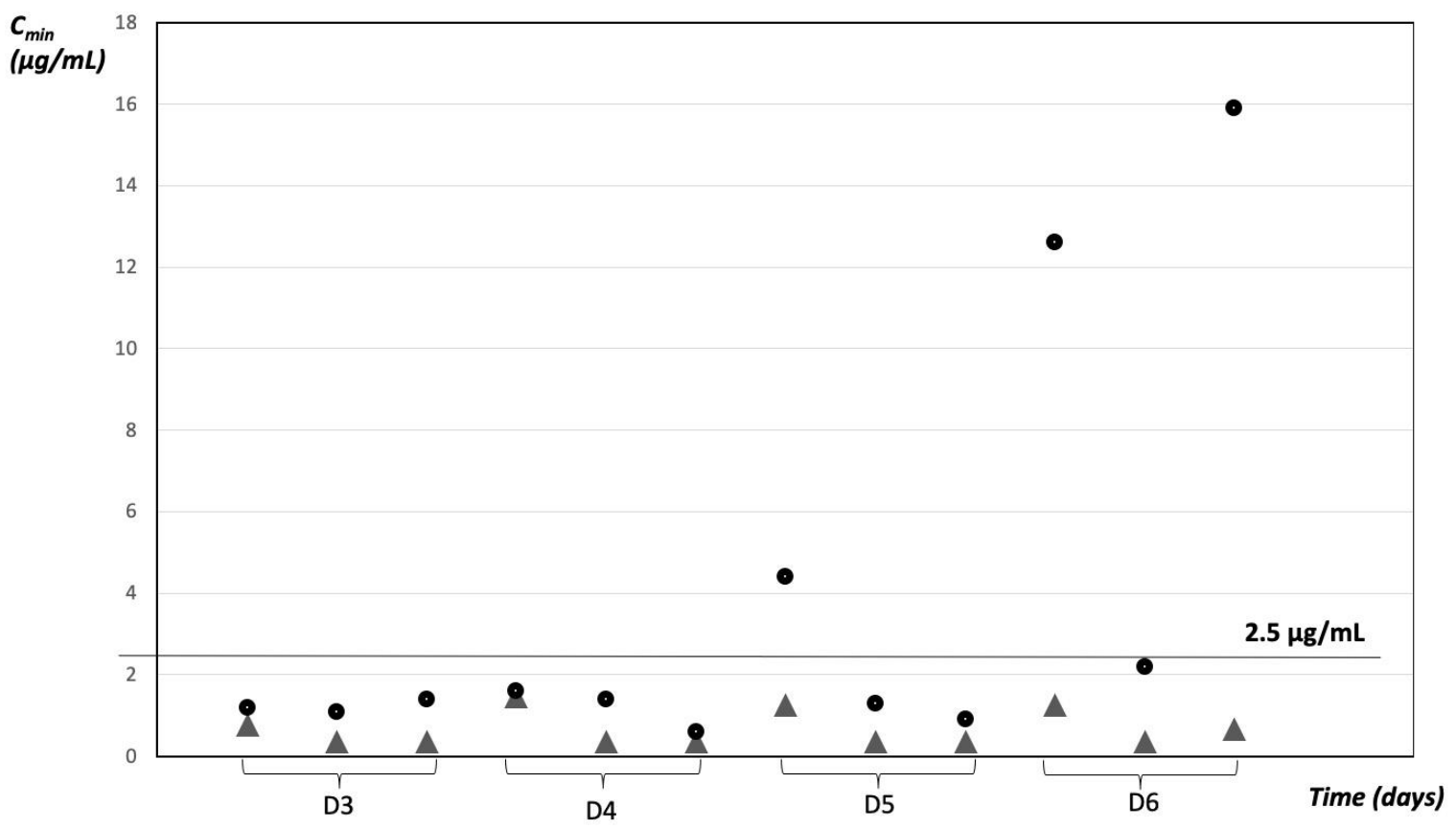

3.5. Acute kidney injury

Results of serum creatinine concentration and clearance of urinary creatinine are presented in Table 3. All the serum creatinine concentrations were in the normal range. Some 
variations in urinary creatinine clearance were observed during the study. Based on the previously defined criteria, no sheep developed acute kidney injury.

$\underline{\text { Table 3. Individual creatinine serum concentrations and urinary creatinine clearance measured }}$ during the study (D: day of the study, UV: usual values).

Group 1: sheep with hemodialysis, group 2: sheep without hemodialysis.

\begin{tabular}{|c|c|c|c|c|}
\hline & \multicolumn{2}{|c|}{$\begin{array}{l}\text { Serum creatinine concentration } \\
\quad(\mathrm{mg} / \mathrm{L}, \mathrm{UV} \text { [39]: } 8-20)\end{array}$} & \multicolumn{2}{|c|}{$\begin{array}{l}\text { 1-h urinary creatinine clearance } \\
(\mathrm{mL} / \mathrm{kg} / \mathrm{min}, \mathrm{UV}[15]: 1.12-1.52)\end{array}$} \\
\hline & Group 1 & Group 2 & Group 1 & Group 2 \\
\hline D2 & 14.1 & 8.0 & 0.7 & 2.1 \\
\hline D3 & 13.1 & 8.4 & 0.8 & 1.8 \\
\hline D4 & 12.9 & 7.9 & 1.4 & 1.0 \\
\hline D5 & 14.3 & 7.6 & 0.6 & 2.2 \\
\hline D6 & 13.8 & 8.0 & 1.5 & 1.7 \\
\hline D2 & 10.3 & 8.1 & 2.0 & 2.2 \\
\hline D3 & 9.0 & 8.0 & 2.2 & 2.2 \\
\hline D4 & 9.3 & 7.3 & 2.0 & 1.1 \\
\hline D5 & 9.7 & 7.5 & 1.2 & 2.1 \\
\hline D6 & 9.4 & 7.4 & 2.5 & 2.2 \\
\hline D2 & 12.0 & 8.2 & 1.5 & 2.6 \\
\hline D3 & 12.6 & 7.8 & 1.7 & 2.3 \\
\hline D4 & 9.4 & 7.0 & 2.1 & 2.5 \\
\hline D5 & 9.9 & 7.2 & 2.2 & 2.7 \\
\hline D6 & 11.3 & 8.2 & 1.5 & 2.4 \\
\hline
\end{tabular}

4. Discussion

This study showed that hemodialysis reduces the $\mathrm{C}_{\min }$ and time of exposure to a concentration of at least $2.5 \mu \mathrm{g} / \mathrm{mL}$ after the injection of a high dose of amikacin. A trend toward reducing AUC with hemodialysis was also observed. Thus, this technique seems interesting in preventing nephrotoxic risk induced by a high-dose aminoglycoside regimen.

Amikacin has a dose-dependent bactericidal efficacy. The usual therapeutic goal is a $\mathrm{C}_{\max } / \mathrm{MIC}$ ratio $\geq 8$ [9], yielding serum concentrations exceeding $64 \mu \mathrm{g} / \mathrm{mL}$ for sensitive strains or greater than $128 \mu \mathrm{g} / \mathrm{mL}$ for strains with intermediate resistance [10]. Pharmacokinetic parameters of hydrophilic antibiotics are strongly altered in patients with sepsis, due to a major increase in the volume of distribution in these patients. This increase seems to be correlated to the severity of sepsis [8]. So higher loading doses may be required to obtain clinically relevant peak concentration values, as is occurring in practice. However, several studies highlight the difficulties encountered in these patients to achieve the therapeutic goals even with doses as high as 15 to $30 \mathrm{mg} / \mathrm{kg}$. In these studies, a serum 
concentration of amikacin $\geq 64 \mu \mathrm{g} / \mathrm{mL}$ was obtained in less than $77 \%$ of cases $[4,5,8,11]$. That is why we chose a $50-\mathrm{mg} / \mathrm{kg}$ amikacin dose. In the current study, we obtained high peaks, with median $\mathrm{C}_{\max }$ close to $210 \mu \mathrm{g} / \mathrm{mL}$. Nevertheless, the volume of distribution of amikacin in sheep was $0.2 \mathrm{~L} / \mathrm{kg}$, comparable to that described in the literature [20,21], but half that of the mean volume of distribution of a human patient in ICU [4,5,7,11]. For an increased volume of distribution in a critically ill patient, the dose of $50 \mathrm{mg} / \mathrm{kg}$ would provide a median $\mathrm{C}_{\max }$ of about $100 \mu \mathrm{g} / \mathrm{mL}$, higher than $64 \mu \mathrm{g} / \mathrm{mL}$ and relatively close to the second therapeutic goal. It therefore seems appropriate to use that dose in clinical practice for the treatment of infection caused by bacteria with a MIC of $8 \mu \mathrm{g} / \mathrm{mL}$. The administration of higher doses of amikacin, associated with longer sessions of hemodialysis should be considered for intermediate resistance strains.

All renal replacement techniques are efficient for the elimination of amikacin from the blood. Continuous hemodiafiltration gave an amikacin clearance of $40 \mathrm{~mL} / \mathrm{min}$ or around $89 \%$ of the mean total body clearance [22]; intermittent hemodialysis gave a clearance of $37.5 \mathrm{~mL} / \mathrm{min}$ amikacin, approximately $21 \%$ of total clearance (for hemodialysis sessions of 3 to 4 hours) [23]. In the current study, the clearance of amikacin related to hemodialysis was very close to values found in the literature: clearance of $35.6 \mathrm{~mL} / \mathrm{min}$ or $14 \%$ of total clearance for sessions of $4 \mathrm{~h}$. The hydrophilic nature of amikacin and its low protein binding fraction make possible removal with renal replacement therapy by diffusion, convection and adsorption on the membranes of the artificial kidney [22-24]. Few studies exist regarding the removal of amikacin by different renal replacement therapy so it is difficult to determine which technique is the most effective. Some authors emphasize the superiority of hemodiafiltration over hemodialysis for the treatment of renal failure [25]. However, comparison of studies is complex, considering the differences between the renal replacement therapy parameters in the studies, as the elimination of amikacin seems to be correlated with these parameters [26]. The choice of hemodialysis in our study is based on literature and the technical expertise of our team: although some studies show a reduction of side effects with hemofiltration or hemodiafiltration, this benefit remains to be confirmed [27-29]. In addition, there is no consensus on the best choice of renal replacement therapy, and all are still used today $[3,22,26]$. The choice of intermittent sessions versus continuous renal replacement therapy was a technical choice: continuous renal replacement therapy could be technically complex in animals. Besides, continuous techniques have not shown their superiority over intermittent sessions [30,31]. 
The accumulation of aminoglycosides in renal tubular cells is responsible for their nephrotoxicity and limits their use, especially in critically ill patients [32]. The toxicity is correlated to the exposure, expressed as $\mathrm{C}_{\min }$ or AUC [12]. In the current study, even with this small sample, the $\mathrm{C}_{\min }$ and time spent above a concentration $>2.5 \mu \mathrm{g} / \mathrm{mL}$ were significantly lower in the dialyzed sheep. The AUC also tended to be lower in this group. These results demonstrate the effect of hemodialysis in the prevention of nephrotoxicity. Similar findings were described in a retrospective study [3] and a case report [6]. Despite the administration of high doses of aminoglycosides, $\mathrm{C}_{\min }$ remained low. There was no direct link between $\mathrm{C}_{\max }$ and toxicity: indeed, renal accumulation was saturated when the serum concentration of amikacin was exceeding $15 \mu \mathrm{g} / \mathrm{mL}$ [6]. So theoretically, there is no limitation to increase the administrated dose of amikacin for a patient if elimination is increased, which is possible with renal replacement therapy. As simulations show that to obtain a satisfactory clinical response against bacteria with MIC $=16 \mu \mathrm{g} / \mathrm{mL}$, the administered doses of amikacin caused AKI in $100 \%$ of the patients [32], combination with renal replacement therapy seems to be a good clinical choice.

No sheep developed AKI in our study. This observation could be explained by the short period of experimentation over which the study was conducted and by the absence of hemodynamic alterations in healthy sheep. The occurrence of AKI induced by aminoglycosides correlates with the duration of treatment in humans [33]. Acute kidney injury may appear after more than 5 to 7 days of treatment [34]. In an experimental model of AKI induced by the administration of high doses of gentamicin in healthy dogs, 16 days of treatment were needed to observe the occurrence of AKI diagnosed with an increase of $\geq 50 \%$ in serum creatinine concentration [35]. In that study, the measurement of serum creatinine concentration did not seem to be the optimal early biomarker to identify AKI induced by aminoglycosides [31]. Indeed, neutrophil gelatinase-associated urinary lipocalin (NGAL) was able to diagnose AKI over a week before the increase in serum creatinine [35].

The current study has several limitations. First, the small number of animals limited the conclusion of this study. In particular, although the median AUC was clearly lower in dialyzed sheep, this difference did not reach statistical significance probably because of lack of power. Experimentation with large animals is difficult and costly, limiting the use of more animals. However, using a mathematical model allowed increasing the amount of 
data without increasing the number of blood samples, which is an important ethical concern. The choice of ovine model can also be discussed. It has been chosen for several reasons. First, sheep are very calm animals. So unlike other animal models, it is not necessary to anesthetize them for the hemodialysis sessions. This is an advantage because anesthesia is known to induce changes in renal perfusion, which could make the interpretation of the results more difficult [36,37]. Second, our team has much clinical experience with hemodialysis in sheep. However, this model has some limitations. There is no information in the literature about the nephrotoxicity of amikacin in sheep. In addition, sheep have rapid elimination [20,21] compared with critically ill patients [38], leading to low accumulation of amikacin in blood after several days of treatment. In this regard, the healthy sheep model is not fully representative of the pharmacokinetics of amikacin observed in ICU patients.

\section{Conclusion}

The current study shows, in a sheep model, that hemodialysis reduces $\mathrm{C}_{\min }$, exposure time to amikacin and AUC after injection of high dose of amikacin $(50 \mathrm{mg} / \mathrm{kg})$, responses that are known to be involved in the risk of nephrotoxicity of amikacin. Renal replacement therapy sessions may thus be useful in preventing kidney failure when treating infections with multidrug-resistant Gram-negative bacteria, with intermediate sensitivity to amikacin, requiring the administration of high doses of amikacin. Further study is required to evaluate this technique in ICU patients.

\section{Acknowledgments}

The authors thank Alexis Fabre for his help and all the staff of the Claude Bourgelat Institute that hosted the study. They also thank Sabine Cohen, Solange Couturier and Thierry Buronfosse for the serum dosage. They are also gratefull to Pr Roger Jelliffe for his advices along this work.

Funding: This work was supported by VetAgro Sup (grant “Jeune chercheur").

Conflicts of interest: None

Ethical approval: This study was approved by the Ethics Committee of VetAgro Sup with the agreement 1548-V2. 
[1] Karam G, Chastre J, Wilcox MH, Vincent J-L. Antibiotic strategies in the era of multidrug resistance. Crit Care 2016;20:136. doi:10.1186/s13054-016-1320-7.

[2] Vincent J-L, Bassetti M, François B, Karam G, Chastre J, Torres A, et al. Advances in antibiotic therapy in the critically ill. Crit Care 2016;20. doi:10.1186/s13054-016-1285-6.

[3] Brasseur A, Hites M, Roisin S, Cotton F, Vincent J-L, De Backer D, et al. A high-dose aminoglycoside regimen combined with renal replacement therapy for the treatment of MDR pathogens: a proof-of-concept study. J Antimicrob Chemother 2016;71:1386-94. doi:10.1093/jac/dkv491.

[4] Gálvez R, Luengo C, Cornejo R, Kosche J, Romero C, Tobar E, et al. Higher than recommended amikacin loading doses achieve pharmacokinetic targets without associated toxicity. Int J Antimicrob Agents 2011;38:146-51. doi:10.1016/j.ijantimicag.2011.03.022. [5] Duszynska W, Taccone FS, Hurkacz M, Kowalska-Krochmal B, Wiela-Hojeńska A, Kübler A. Therapeutic drug monitoring of amikacin in septic patients. Crit Care 2013;17:R165. doi:10.1186/cc12844.

[6] Layeux B, Taccone FS, Fagnoul D, Vincent J-L, Jacobs F. Amikacin Monotherapy for Sepsis Caused by Panresistant Pseudomonas aeruginosa. Antimicrob Agents Chemother 2010;54:4939-41. doi:10.1128/AAC.00441-10.

[7] Taccone FS. Optimising amikacin regimens in septic patients. Int J Antimicrob Agents 2012;39:264-5. doi:10.1016/j.ijantimicag.2011.10.007.

[8] Taccone FS, Laterre P-F, Spapen H, Dugernier T, Delattre I, Layeux B, et al. Revisiting the loading dose of amikacin for patients with severe sepsis and septic shock. Crit Care 2010;14:R53. doi:10.1186/cc8945.

[9] Moore RD, Smith CR, Lietman PS. The association of aminoglycoside plasma levels with mortality in patients with gram-negative bacteremia. J Infect Dis 1984;149:443-8.

[10] EUCAST. European Committee on Antimicrobial Susceptibility Testing Breakpoint tables for interpretation of MICs and zone diameters 2016.

http://www.eucast.org/fileadmin/src/media/PDFs/EUCAST_files/Breakpoint_tables/v_6.0_Br eakpoint_table.pdf (accessed October 7, 2016).

[11] Roger C, Nucci B, Louart B, Friggeri A, Knani H, Evrard A, et al. Impact of $30 \mathrm{mg} / \mathrm{kg}$ amikacin and $8 \mathrm{mg} / \mathrm{kg}$ gentamicin on serum concentrations in critically ill patients with severe sepsis. J Antimicrob Chemother 2016;71:208-12. doi:10.1093/jac/dkv291.

[12] Rybak MJ, Abate BJ, Kang SL, Ruffing MJ, Lerner SA, Drusano GL. Prospective Evaluation of the Effect of an Aminoglycoside Dosing Regimen on Rates of Observed Nephrotoxicity and Ototoxicity. Antimicrob Agents Chemother 1999;43:1549-55.

[13] Mazzaferro EM, Ford RB. Section I - Emergency Care. Kirk Bistners Handb. Vet. Proced. Emerg. Treat. Ninth Ed., Saint Louis: W.B. Saunders; 2012, p. 1-294.

[14] Wellman ML, DiBartola SP, Kohn CW. Chapter 1 - Applied Physiology of Body Fluids in Dogs and Cats. Fluid Electrolyte Acid-Base Disord. Small Anim. Pract. Fourth Ed., Saint Louis: W.B. Saunders; 2012, p. 2-25.

[15] Nawaz M, Shah BH. Renal clearance of endogenous creatinine and urea in sheep during summer and winter. Res Vet Sci 1984;36:220-4.

[16] ANSM. Mise au point sur le bon usage des aminosides administrés par voie injectable : gentamicine, tobramycine, nétilmicine, amikacine. 2011.

[17] Taccone FS, de Backer D, Laterre P-F, Spapen H, Dugernier T, Delattre I, et al. Pharmacokinetics of a loading dose of amikacin in septic patients undergoing continuous renal replacement therapy. Int J Antimicrob Agents 2011;37:531-5.

doi:10.1016/j.ijantimicag.2011.01.026. 
[18] Neely M, van Guilder M, Yamada W, Schumitzky A, Jelliffe R. Accurate detection of outliers and subpopulations with Pmetrics, a non-parametric and parametric pharmacometric modeling and simulation package for R. Ther Drug Monit 2012;34:467-76.

doi:10.1097/FTD.0b013e31825c4ba6.

[19] Bergstrand M, Hooker AC, Wallin JE, Karlsson MO. Prediction-corrected visual predictive checks for diagnosing nonlinear mixed-effects models. AAPS J 2011;13:143-51. doi:10.1208/s12248-011-9255-Z.

[20] Carli S, Montesissa C, Sonzogni O, Madonna M, Said-Faqi A. Comparative pharmacokinetics of amikacin sulphate in calves and sheep. Res Vet Sci 1990;48:231-4.

[21] Haritova A, Lashev L. Pharmacokinetics of amikacin in lactating sheep. Vet Res Commun 2004;28:429-35.

[22] D'Arcy DM, Casey E, Gowing CM, Donnelly MB, Corrigan OI. An open prospective study of amikacin pharmacokinetics in critically ill patients during treatment with continuous venovenous haemodiafiltration. BMC Pharmacol Toxicol 2012;13:14. doi:10.1186/20506511-13-14.

[23] Armstrong DK, Hodgman T, Visconti JA, Reilley TE, Garner WL, Dasta JF. Hemodialysis of amikacin in critically ill patients. Crit Care Med 1988;16:517-20.

[24] Tian Q, Gomersall CD, Ip M, Tan PE, Joynt GM, Choi GYS. Adsorption of Amikacin, a Significant Mechanism of Elimination by Hemofiltration. Antimicrob Agents Chemother 2008;52:1009-13. doi:10.1128/AAC.00858-07.

[25] Kerr PB, Argilés A, Flavier J-L, Canaud B, Mion CM. Comparison of hemodialysis and hemodiafiltration: A long-term longitudinal study. Kidney Int 1992;41:1035-40. doi:10.1038/ki.1992.157.

[26] Lam SW, Bauer SR. Amikacin Pharmacokinetics During Continuous Veno-Venous Hemodialysis. Infect Dis Ther 2013;2:217-26. doi:10.1007/s40121-013-0012-8.

[27] Misset B, Timsit J-F, Chevret S, Renaud B, Tamion F, Carlet J. A randomized crossover comparison of the hemodynamic response to intermittent hemodialysis and continuous hemofiltration in ICU patients with acute renal failure. Intensive Care Med 1996;22:742-6. doi:10.1007/BF01709515.

[28] Swartz RD, Messana JM, Orzol S, Port FK. Comparing continuous hemofiltration with hemodialysis in patients with severe acute renal failure. Am J Kidney Dis 1999;34:42432. doi:10.1016/S0272-6386(99)70068-5.

[29] Nistor I, Palmer SC, Craig JC, Saglimbene V, Vecchio M, Covic A, et al. Haemodiafiltration, haemofiltration and haemodialysis for end-stage kidney disease. Cochrane Database Syst Rev 2015;5:CD006258. doi:10.1002/14651858.CD006258.pub2. [30] Chater K, Kellum JA. Continuous vs. intermittent hemodialysis: with which spin will my patient win? Crit Care 2007;11:313. doi:10.1186/cc6134.

[31] Uehlinger DE, Jakob SM, Ferrari P, Eichelberger M, Huynh-Do U, Marti H-P, et al. Comparison of continuous and intermittent renal replacement therapy for acute renal failure. Nephrol Dial Transplant 2005;20:1630-7. doi:10.1093/ndt/gfh880.

[32] Drusano GL, Ambrose PG, Bhavnani SM, Bertino JS, Nafziger AN, Louie A. Back to the Future: Using Aminoglycosides Again and How to Dose Them Optimally. Clin Infect Dis 2007;45:753-60. doi:10.1086/520991.

[33] Bertino JS, Booker LA, Franck PA, Jenkins PL, Franck KR, Nafziger AN. Incidence of and significant risk factors for aminoglycoside-associated nephrotoxicity in patients dosed by using individualized pharmacokinetic monitoring. J Infect Dis 1993;167:173-9.

[34] Gauzit R. Actualités en antibiothérapie - Aminosides toujours et encore: bon usage et suivi thérapeutique. Réanimation 2010;20:290-8. doi:10.1007/s13546-010-0106-1.

[35] Palm C a., Segev G, Cowgill L d., LeRoy B e., Kowalkowski K 1., Kanakubo K, et al. Urinary Neutrophil Gelatinase-associated Lipocalin as a Marker for Identification of Acute 
Kidney Injury and Recovery in Dogs with Gentamicin-induced Nephrotoxicity. J Vet Intern Med 2016;30:200-5. doi:10.1111/jvim.13819.

[36] Aziz MA, Carlyle SS. Cardiovascular and Respiratory Effects of Xylazine in Sheep. Zentralblatt Für Veterinärmedizin Reihe A 1978;25:173-80. doi:10.1111/j.1439-

0442.1978.tb00917.x.

[37] Gómez de Segura IA, Tendillo FJ, Mascías A, Santos M, Castillo-Olivares JL, Steffey EP. Actions of xylazine in young swine. Am J Vet Res 1997;58:99-102.

[38] Dalen R van, Vree TB. Pharmacokinetics of antibiotics in critically ill patients. Intensive Care Med 1990;16:S235-8. doi:10.1007/BF01709707.

[39] Aiello SE. The Merck Veterinary Manual. 11th Edition. Merck publishing; 2016. 